\title{
Jordskcelvet i Pakistan - område med voldsom tektonik
}

\section{Af Tine B. Larsen, GEUS}

Så skete det igen! Mindre end et år efter jordskælvet ved Sumatra, som dræbte næsten 300.000 mennesker, blev et tæt befolket område ramt af et kraftigt jordskælv. Lørdag den 8. oktober 2005 kl. 5:50 dansk tid blev den pakistanske del af Kashmir rystet af et kraftigt jordskælv, som målte 7,6 på Richterskalaen.

Jordskælvet medførte omfattende ødelæggelser i det fattige område, hvor husene slet ikke kunne modstå de kraftige rystelser. Veje blev blokeret af store stenskred, og redningsarbejdet blev yderligere vanskeliggjort af talrige kraftige efterskælv - flere op til 6,0 på Richterskalaen - der vedvarende rystede området i ugerne efter det store jordskælv.

Huse, som var delvis beskadigede af hovedskælvet, kollapsede under efter-

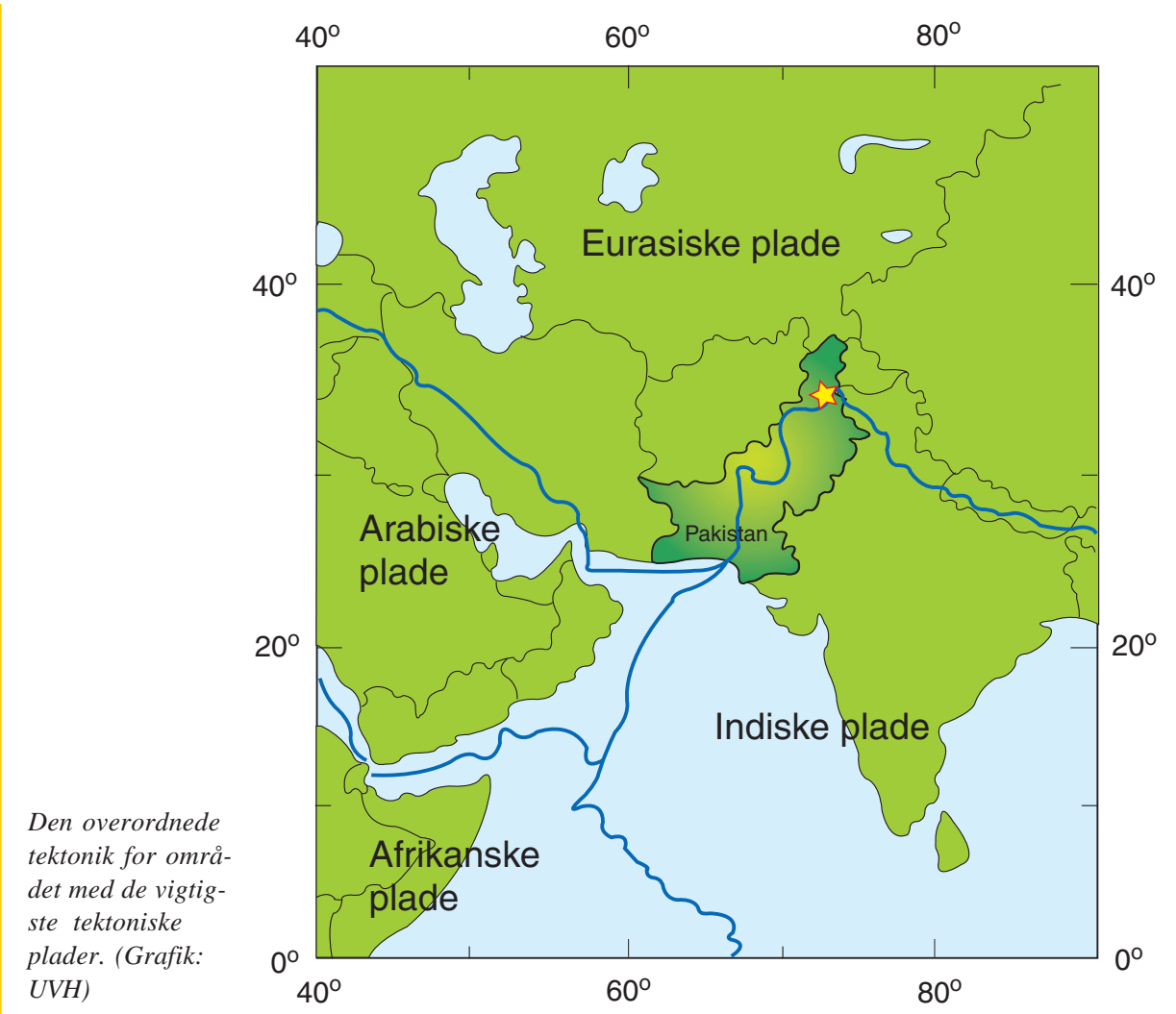

skælvene og gjorde livet ekstra farligt for redningsarbejderne og de overlevende. En meget stor del af husene i byen Muzaffarabad $10 \mathrm{~km}$ fra jordskælvets epicenter blev ødelagt. Det er skønnet at op mod 4 millioner mennesker mistede deres hjem, og over 86.000 blev dræbt i det bjergrige område.

Rystelserne fra jordskælvet kunne mærkes over et stort område, og medførte også ødelæggelser og tab af menneskeliv i Indien, hvor over 1.300 mennesker omkom. Både i Islamabad, New Delhi og Kabul kunne rystelserne tydeligt mærkes, men dog uden at forårsage skader. I søer i regionen, helt til Bangladesh, blev der observeret seiches. Seiches er bølger i vand, som opstår når rystelser fra et jordskælv sætter vandet i svingninger. Disse bølger har intet at gøre med tsunamier, der opstår, når et kraftigt jordskælv har sit epicenter under dybt vand og forårsager en kraftig lodret forskydning af havbunden.

\section{Områdets tektonik}

Det er ikke overraskende, at det nordlige
Pakistan kunne rammes af et kraftigt jordskælv. Den indiske plade, som også Pakistan er en del af, bevæger sig nordpå med ca. 4$4,5 \mathrm{~cm} /$ år. Derved presses den indiske plade med voldsom kraft ned under den eurasiske plade. Det er måske den mægtigste sammenstødszone på jorden, idet begge de involverede plader er kontinentale, der hvor de mases sammen.

Kontinentalplader er tykke og har en lavere massefylde end oceanplader, og lader sig derfor ikke uden videre presse ned under hinanden. Resultatet af sammenstødet er verdens højeste bjergtinder med bl.a. Himalaya-bjergkæden, der står som en markant vidnesbyrd om de voldsomme naturkræfter, der er på spil.

For-bjergene umiddelbart syd for de store bjergkæder gennemskæres af store systemer af overskydningsforkastninger, men de enkelte forkastningers forløb er dårligt kendt. Det skyldes det vanskeligt tilgængelige terræn. Til gengæld kan områdets jordskælv kortlægges ud fra registreringer på de internationale seismologiske netværk - helt uden besværligt feltarbejde. Jordskælvene viser, 
hvor de aktive forkastninger befinder sig. Der kan være mange kilometers usikkerhed på et jordskælvs beregnede epicenter, men når jordskælvene er talrige nok, vil den kraftigste koncentration af beregnede epicentre faktiske placering.

Ikke alle dele af en forkastning er aktive lige ofte. Den samme forkastning kan have både roligt, krybende segmenter, og områder hvor spændinger akkumuleres over lang tid, før pladerne giver efter og flytter sig i et ordentligt ryk. Området ved Muzaffarabad havde indtil d. 8. oktober 2005 ikke oplevet et større jordskælv siden 1974, hvor et jordskælv, som målte ca. 6 på Richterskalaen ramte og ødelagde landsbyen Pattan ca. 85 $\mathrm{km}$ fra Muzaffarabad. Ved den lejlighed blev ca. 5.300 mennesker dræbt, hovedsagelig af stenskred. Det er dog et område, der mange gange årligt rystes af mindre jordskælv.

Det sidste rigtigt store jordskælv i området ligger hundrede år tilbage. Den 4. april 1905 rystedes området knap 300 km længere mod syd-øst af et gigantisk jordskælv. Dette jordskælv er efterfølgende blevet bestemt til 8 på Richterskalaen, men der er nogen usikkerhed på beregningen.

\section{Den indiske plade igen?}

Den indiske plade var involveret i både Kashmir-jordskælvet d. 8/10 2005. Der er imidlertid ikke nogen grund til at tro, at Sumatra-jordskælvet forårsagede Kashmirjordskælvet. Dertil ligger epicentrene alt, alt for langt fra hinanden. Desuden er der gået meget lang tid mellem de to jordskælv, hvilket under alle omstændigheder ville tale imod en direkte sammenhæng.

Begge destruktive jordskælv fandt sted i aktive jordskælvszoner, hvor der med mellemrum forekommer meget kraftige jordfalde pænt sammen med forkastningernes Sumatra-jordskælvet d. 26/12 2004 og i

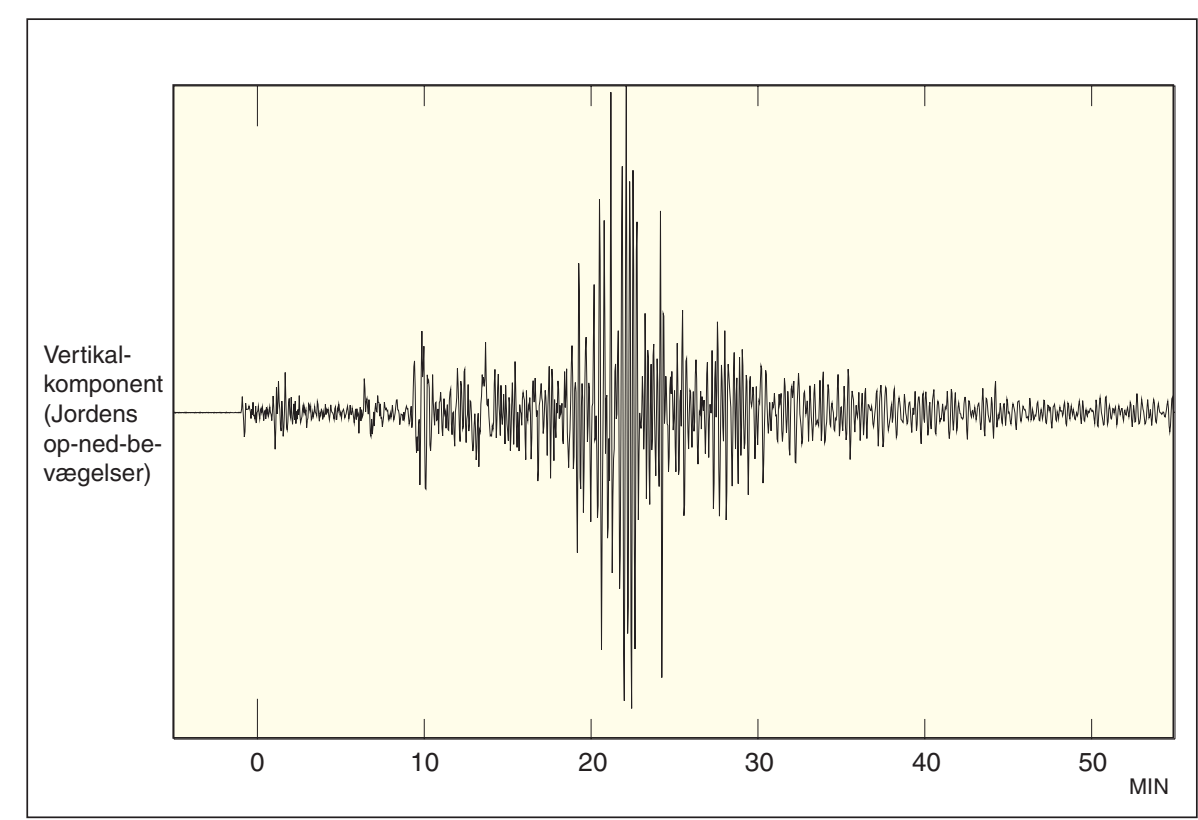

Seismogram der viser en times registrering på målestationen i København. Den første rystelse ses kl 3:59 UTC. (Grafik: GEUS) skælv. At vi på mindre end et år har oplevet to dræbendejordskælv, skyldes entilfældighed.

\section{Efterskælv}

Kashmir har været plaget af mange og kraftige efterskælv. Det første døgn var der det meste af tiden kun 10-20 minutter mellem efterskælvene, hvor op mod halvdelen var over 5 på Richterskalaen, og i det første døgn var der to efterskælv på 6,0 på Richterskalaen. Også d. 9. og 10. oktober blev området rystet af talrige efterskælv, og aktiviteten klingede først for alvor af i november måned.

Fysisk set fungerer efterskælvene som en finjustering efter hovedskælvet. Hovedskælvet udløser hovedparten af de opbyggede spændinger i undergrunden det pågældende sted, men nye spændinger opstår som følge af skælvet, og typisk vil ikke alle de oprindelige spændinger være udløst. Efterskælvene hjælper med til at bringe området tættere på en spændingsmæssig ligevægt.

\section{Danske registreringer}

Jordskælvet blev registreret klart og tydeligt på de danske og grønlandske seismografer. De tog kun de første rystelser 8 minutter og

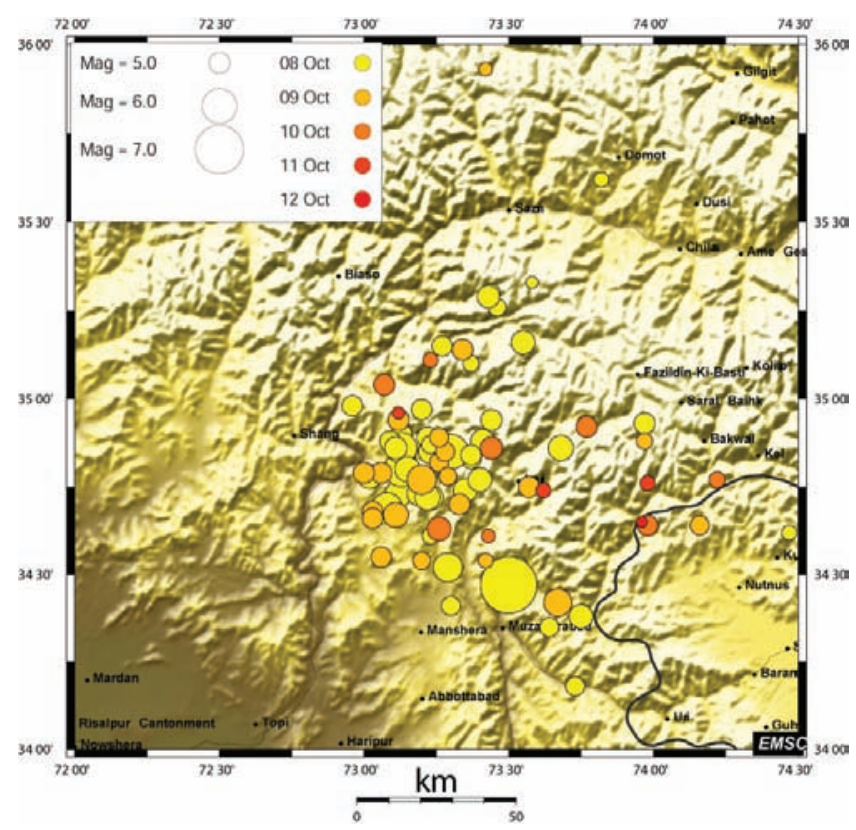

Der var mange og kraftige efterskcelv i ugerne efter $d$. 8. oktober 2005. Epicentrene er beregnet af et automatisk system, og ikke alle har vceret igennem den scedvanlige kvalitetskontrol endnu. (Grafik: venligst udlånt af European Mediterranean Seismological Centre) 
28 sekunder at nå fra Kashmir til København. GEUS' seismografer indgår i de internationale netværk af seismografer, der overvåger jordskælv overalt på kloden, og data bliver så hurtigt som det er muligt sendt videre til de internationale datacentre, der beregner jordskælvets epicenter og styrke. Af hensyn til redningsarbejdet er det vigtigt at kende epicenteret hurtigt, da mennesker i de berørte områder ofte er ude af stand til at bede om hjælp efter voldsomme jordskælv, fordi kommunikationslinjer og infrastruktur er brudt sammen.

\section{Referencer:}

International Seismological Centre, http:/ /www.isc.ac.uk/

European Mediterranean Seismological Centre, http://www.emsc-csem.org/

National Earthquake Information Center, USGS, http://wwwneic.cr.usgs.gov/

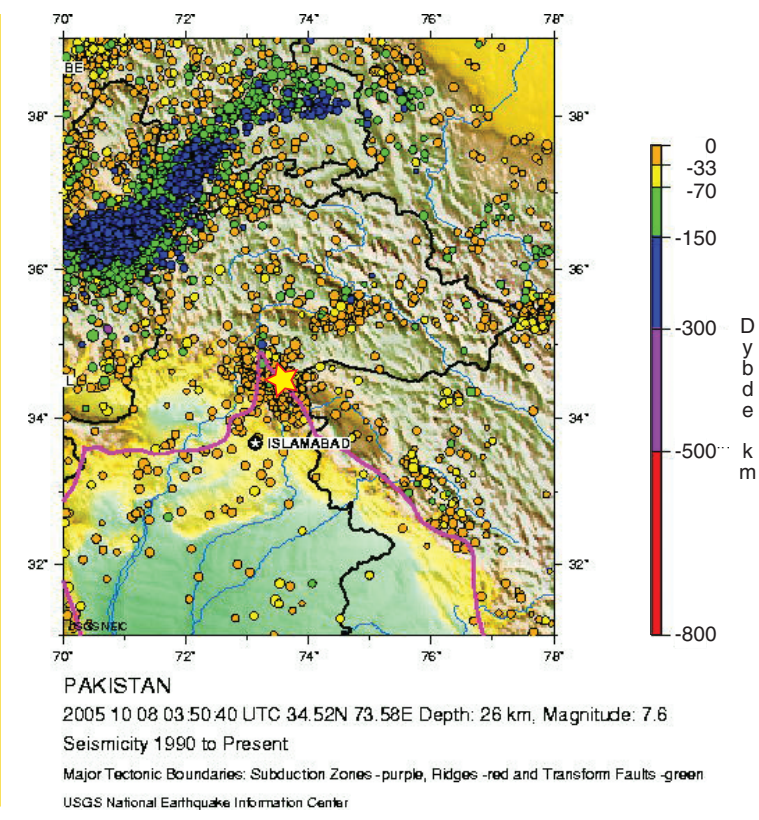

Der er ofte jordskcelv i Kashmir, som gennemskceres af den nordlige kant af den indiske plade (lilla linje). Prikkerne viser de registerede jordskcelv siden 1990, og prikkernes farve viser jordskcelvets dybde. (Grafik: U.S. Geological Survey)

\section{Radioaktive isotoper antyder eksistensen af ukendt lag i Jorden}

Af Jan Thøgersen, Kemisk Institut, Aarhus Universitet

Overskud af ${ }^{142} \mathrm{Nd}$ i den moderne Jord Jordens sammensætning af grundstoffer og isotoper antages fundamentalt set at afspejle forekomsten i det støv og de sten, som medgik til Jordens dannelse. Samme sammensætning forventes bevaret i primitive meteoritter også kaldet kondritter. Specielt forventes isotopfordelingen af neodymium og de øvrige sjældne jordarter at være den samme som i kondritterne.

Prøver foretaget i 1980'erne viste, at den relative forekomst af neodymiums isotoper ${ }^{142} \mathrm{Nd} /{ }^{144} \mathrm{Nd}$ i kondritter var den samme, som man fandt i Jordens skorpe og magma med udtagelse af nogle få afvigelser i Jordens ældste klipper fundet på Grønland [1]. Forbedrede målinger foretaget af Maud Boyet og Richard Carlson har til geologers store overraskelse vist, at denne afvigelse er ægte nok - den moderne Jord har et overskud af ${ }^{142} \mathrm{Nd}$ på $20 \mathrm{ppm}$ i forhold til kondritterne! [2,3] Det betyder, ifølge Stanley Hart fra Woods Hole Oceanographic Institution, at enten er Jorden dannet af materiale forskelligt fra det i kondrit-meteoritter, eller også er den del af Jorden, som geokemikere har adgang til, ikke repræsentativ for Jorden som helhed. Hvis man vil holde fast i den fundamentale antagelse om en kondrittisk Jord, konkluderer Boyet og Carlson, at der må findes et skjult reservoir fuld af sten med et underskud af ${ }^{142} \mathrm{Nd}$. I årevis har geokemikere kæmpet med opfattelsen af, at der kunne eksistere et kemisk afvigende lag mellem Jordens kerne og den tilgængelige del af kappen. Nu er der noget, der tyder på, at det virkeligt forholder sig sådan.

\section{Wolfram-hafnium-systemet}

Jordens ældste bjergarter er ca. 4 milliarder år gamle. Direkte beviser på, hvad der skete på Jorden 500 millioner år tidligere, er ret sparsomme. Ifølge nuværende modeller var varmen fra meteornedslag og kortlivede isotoper nok til delvist at smelte planeten og skille de lette silikater fra tungere metaller. Isotopvariationer kan fastslå tidsforløbet af disse begivenheder. Således har wolframhafnium-systemet været benyttet til at fastlægge, at Jordens kerne senest kan være dannet 30 millioner år efter solsystemets fødsel. Ligeledes viser Boyet og Carlsons målinger baseret på samarium-neodymiumsystemet, at den kemiske sammensætning af Jordens kappe forandredes inden for de første 30-50 millioner år af Jordens historie, formentlig lige efter dannelsen af kernen.

Boyet og Carlsons målinger har også afstedkommet en revidering af standardmodellen for kappens geokemi. Traditionelt har geokemikere antaget, at dannelsen af Jordens skorpe - ved smeltning af kappens bestanddele med efterfølgende transport gennem revner i kappen - sker på geologisk tid. Ifølge standardmodellen vurderes den del, der medgår til dannelsen af skorpen til mellem $1 / 2$ og $1 / 3$ af kappen, mens resten forbliver uberørt. Men holder Boyet og Carlsons teori om dannelsen af et skjult reservoir inden for $1 \%$ af Jordens levetid, skal næsten hele kappen smeltes under dannelsen af skorpen.

\section{Et skjult reservoir}

Teorien om et skjult reservoir hjælper også med til at forklare uoverensstemmelsen mellem mængden af varme, som kommer fra tilgængelige radioaktive forekomster og den varmeproduktion, der er nødvendig for at forklare Jordens konstante afkøling. Boyet og Carlson vurderer, at et skjult reservoir, uanset størrelse, vil indeholde ca. $43 \%$ af Jordens uran, thorium og kalium. Endvidere vil et varmt radioaktivt lag omkring Jordens kerne virke som et tæppe og kan måske forklare, hvorfor den ydre kappe forbliver delvist smeltet og fortsætter med at skabe det geomagnetiske felt.

\section{Litteratur:}

1. S. B. Jacobsen, G. J. Wasserburg.

Earth Planet. Sci. Lett. 67, 137 (1984); C. L Harper Jr., S. B Jacobsen, Nature 360, 728 (1992)

2. M. Boyet et al. Earth Planet. Sci. Lett. 214, 427 (2003); Se også G. Caro et al., Nature 423, 428 (2003)

3. M. Boyet, R. Carlson, Science 309, 576 (2005) 